\title{
Physical and Microbiological Qualities of Kampong-Broiler Crossbred Chickens Meat Raised in Different Stocking Densities
}

\author{
C. A. Patria ${ }^{a *}$, R. Afnan ${ }^{b}$, \& I. I. Arief ${ }^{b}$ \\ aStudy Program of Animal Production and Technology, Faculty of Animal Science, Graduate School, \\ Bogor Agricultural University \\ ${ }^{b}$ Department of Animal Production and Technology, Faculty of Animal Science, Bogor Agricultural University \\ Jalan Agatis, Kampus IPB Darmaga Bogor 16680, Indonesia \\ (Received 23-04-2016; Reviewed 14-07-2016; Accepted 04-10-2016)
}

\begin{abstract}
The crossbreeding between broiler and kampong chickens has been performed to develop a kampong-broiler strain chicken. The chicken stocking condition needs more attention as a part of animal welfare. This study was performed to identify the relationship between the stocking density and the stress based on Temperature Humidity Index (THI) and the effect of stocking density on meat quality, i.e., physical, microbiological, and organoleptic. Ninety DOCs of Kampong-Broiler (KB) were assigned into a completely randomized design with 3 treatments of stocking density i.e., 8,10 , and $12 \mathrm{birds} / \mathrm{m}^{2}$. Each treatment was replicated 3 times. The experimental chickens were housed in 9 blocks of housing each with $1 \times 1 \mathrm{~m}^{2}$ size. Data on physical and microbiology of meat qualities were analyzed with analysis of variance and continued with Duncan's multiple range test. The organoleptic data were analyzed by using Kruskal-Wallis test. The result showed that the stocking density did not significantly affect the physical and hedonic quality of KB chicken's breast. The stocking densities significantly affected $(\mathrm{P}<0.05)$ the microbiological variables of breast meat. The average value of THI during maintenance reached $28.98 \pm 1.25-29.33 \pm 1.32^{\circ} \mathrm{C}$. The higher the animal density the higher the THI value that correlated to the stress condition. However, high stocking density did not affect the physical and hedonic quality of breast meat, thus it can be accepted by the consumers. The higher the stocking density the higher the total plate count, Escherichia coli, and Staphylococcus aureus, without the presence of Salmonella sp. The meat quality of KB chickens raised in the stocking density of $10 \mathrm{birds} / \mathrm{m}^{2}$ meets the requirement of SNI 01-3924-2009.
\end{abstract}

Key words: Kampong-broiler crossbred, stocking density, meat quality, THI

\section{ABSTRAK}

Upaya untuk mengembangkan ayam kampung dilakukan melalui persilangan dengan ayam broiler. Kondisi kandang yang nyaman merupakan bagian dari kesejahteraan hewan. Tujuan penelitian ini ialah mengidentifikasi cekaman akibat kepadatan kandang berdasarkan THI (Temperature Humidity Index) dan mengidentifikasi pengaruh kepadatan kandang pada kualitas daging, yaitu fisik, mikrobiologi, dan organoleptik. Sebanyak 90 DOC KB (Kampung Broiler) digunakan dalam penelitian ini. Ayam KB ditempatkan pada 9 petak (ukuran 1x1 $\mathrm{m}^{2}$ ) pada kandang semi closed house dengan 3 perlakuan. Setiap perlakuan dilakukan ulangan sebanyak 3 kali. Perlakuan kepadatan kandang yang berbeda yang digunakan ialah 8,10 , dan $12 \mathrm{ekor} / \mathrm{m}^{2}$. Peubah fisik dan mikrobiologis dianalisis menggunakan ANOVA dan dilanjutkan dengan uji jarak berganda Duncan. Data organoleptik diuji secara nonparametrik (Kruskal-Wallis). Hasil penelitian menunjukkan bahwa kepadatan kandang tidak berpengaruh nyata terhadap kualitas fisik dan mutu hedonik daging dada ayam KB. Kepadatan kandang berbeda memberikan pengaruh nyata $(\mathrm{P}<0.05)$ terhadap kualitas mikrobiologi daging dada. Rata-rata nilai THI selama pemeliharaan mencapai $28.98 \pm 1.25-29.33 \pm 1.32{ }^{\circ} \mathrm{C}$. Kepadatan kandang yang tinggi meningkatkan nilai THI yang berkorelasi dengan meningkatnya cekaman tetapi tidak mempengaruhi kualitas fisik dan mutu hedonik daging dada ayam KB sehingga masih dapat diterima oleh konsumen. Kepadatan kandang yang tinggi meningkatkan TPC, Escherichia coli, Staphylococcus aureus, tetapi Salmonella sp. tidak ditemukan. Kualitas daging masih memenuhi standar hingga kepadatan 10 ekor/ $\mathrm{m}^{2}$ berdasarkan SNI 01-3924-2009.

Kata kunci: persilangan ayam kampung, broiler, kepadatan, kualitas daging, THI

*Corresponding author:

E-mail: cintiaagustin90@gmail.com 


\section{INTRODUCTION}

Kampong chicken is the most dominant and accepted poultry commodity in the rural community. The low reproductive and growth rates of kampong chickens cause a low meat production. Broiler chicken is a strain of chicken with a high productivity, especially in meat production. The effort to improve the meat productivity of kampong chickens were conducted by crossbreeding, especially with broiler.

The increased stocking density in poultry industry affects the productivity due to the competition that eventually decreases the growth rate (Zuowei et al., 2011). This condition may lead to an unoptimum productivity. According to Berri et al. (2008), the higher or lower stocking density affects the carcass quality, especially the breast and thigh. Besides, the stock density is the main priority of animal welfare that affects the poultry products (Vanhonacker et al., 2009). The higher stocking density reduces the broiler performance due to several factors. The side effects of high stocking density are the increase in ammonia pollution in the cage and reduction in the access to feed and water, in addition to the poor air quality caused by the insufficient air exchange. The high environment temperature causes a reduction of heat dissipation from the animal's body to the environment (Feddes et al., 2002). According to Iskandar et al. (2014), the stocking density of 8 birds /0.405 $\mathrm{m}^{2}$ for Wareng-Tangerang chicken could provide the life comfort based on the genetic potential. Meanwhile, the density of 15 birds $/ \mathrm{m}^{2}$ affects the performance of grower laying hens (Gustira \& Kurtini, 2015).

Meat is a food stuff with a high potential hazards of biological, physical, and chemical contaminations. Meat should be hazardous-safe and free from microbial contamination or other contents. Jayalakshmi et al. (2009) reports that the stocking density can affect the bacterial composition of litter that is related to the change in the gut microflora. Cengiz et al. (2015) finds that carcass yields are not significantly affected by the stocking density. Thus, this study aimed to identify the relationship between stress and stocking density based on Temperature Humidity Index (THI) and the effect of stocking density on meat quality based on physical, microbiological, and sensory parameters.

\section{MATERIALS AND METHODS}

\section{Experimental Design}

The crossbreeding was performed naturally by mating of kampong rooster with broiler hen with the ratio of 1:5 for each coop. The daily egg collection was performed every morning and afternoon. The rearing was performed for 12 weeks in 9 plots each with the size of 1x1 m². A number of 90 birds each plot contained an experimental unit with different densities of 8,10 , and 12 birds $/ \mathrm{m}^{2}$, thus 3 groups were served as replicates. The coop's floor used paddy chaff, equipped with the feeder, drinker, thermometer, and heater (incandescent light). The feed and drinking water were available ad libitum and feed and water consumptions were calculated daily.
After 12 weeks of rearing, 30\% of the population of each plot was randomly selected for slaughtering, and each brisket per sample was separated to measure physical, microbiological, and sensory parameters of meat quality.

\section{Physical Quality Analyses}

pH value (Kirmaci \& Singh, 2012). pH of chicken brisket was measured in duplicate according to a direct probe method using pH meter (Hanna Instruments, USA) that had been calibrated using $\mathrm{pH} 4$ and $\mathrm{pH} 7$ buffer solutions.

Water Holding Capacity (Honikel \& Hamm, 1994). An amount of $0.3 \mathrm{~g}$ meat was placed on filter paper between 2 stainless steel plates, then $35 \mathrm{~kg}$ weight was loaded to the meat for $5 \mathrm{~min}$. The flattened meat-covered area and wet area surrounding the meat would appear in the filter paper. The wet area was obtained by the subtraction of the whole wet area appeared with the flattened meatcovered area. WHC was calculated based on the percentage between the wet area and the total area.

$\mathrm{mgH}_{2} \mathrm{O}=$ [wet area $\left.\left(\mathrm{cm}^{2}\right) / 0.0948\right] \times 8.0 \%$

Cooking loss (Tijare et al., 2016). The breast was weighed and cooked in an aluminum foil-covered pan with internal temperature of $76^{\circ} \mathrm{C}$. The temperature was controlled by using a digital thermometer. The cooked breast was then cooled at room temperature and weighed immediately to calculate the cooking loss.

Tenderness (Bowker et al., 2014). The breast was cooked in vacuum bags at $78^{\circ} \mathrm{C}$. Every breast was sampled by using made corer diameter of $1 \mathrm{~cm}$ and sheared using Warner-Bratzler shear device. The tenderness was recorded as $\mathrm{kg} \mathrm{cm}^{-2}$.

\section{Microbiological Analysis (FDA et al., 2001)}

Nine samples of KB Rooster's breast was used in microbiological analysis. The meat from breast roosters were taken homogeneously from 27 samples. An amount of $25 \mathrm{~g}$ breast was put into $225 \mathrm{~mL}$ buffer pepton water (BPW) and homogenized, then allowed to stand for $30 \mathrm{~min}$ to get a $10^{-1}$ dilution. As much as $1 \mathrm{~mL}$ suspension was pipette-transferred until getting a $10^{-6}$ dilution.

Total Plate Count (TPC) quantitative analysis. As much as $1 \mathrm{~mL}$ suspension from $10^{-4}-10^{-6}$ dilutions was transferred into petridishes in duplicate, then added $20 \mathrm{~mL}$ Plate Count Agar (PCA) medium and homogenized. The petridishes were incubated at $37^{\circ} \mathrm{C}$ for $36 \mathrm{~h}$.

Escherichia coli quantitative analysis. As much as $1 \mathrm{~mL}$ suspension from $10^{-1}-10^{-3}$ dilutions were aseptic-pipetted into petridishes in duplicate, then added $20 \mathrm{~mL}$ Eosin Methylen Blue Agar (EMBA) medium and homogenized. Petridishes were incubated at $37^{\circ} \mathrm{C}$ for $36 \mathrm{~h}$.

Staphylococcus aureus quantitative analysis. As much as $1 \mathrm{~mL}$ suspension from $10^{-1}-10^{-3}$ dilutions were 
aseptic-pipetted in duplicate into petridishes that were already filled with 15-20 mL Baird Parker Agar (BPA) medium $+5 \%$ egg yolk and homogenized. The suspension was then well-spread on the media surface using hockey stick and allowed to stand for $\pm 30 \mathrm{~min}$ at room temperature. The media were incubated upside down at $37^{\circ} \mathrm{C}$ for $36 \mathrm{~h}$

Salmonella sp. quantitative analysis. As much as $1 \mathrm{~mL}$ suspension from $10^{-1}-10^{-3}$ dilutions were aseptic-pipetted in duplicate into petridishes, then added $20 \mathrm{~mL}$ Xylose Lysine Deoxycholate Agar (XLDA) medium and homogenized. The petridishes were incubated upside down at $37^{\circ} \mathrm{C}$ for $36 \mathrm{~h}$.

\section{Sensory Test (Arief et al., 2014)}

The determination of hedonic quality test was conducted according to the principle evaluation of panelists. All of panelists were asked to record the results into the form provided (1-5 scales). Forty trained panelists were employed to provide the explanation and guidance for hedonic quality test-aroma, tasting, texturing, and color appearance with scoring.

\section{Temperature-Humidity Index (THI) (Tao \& Xin, 2003)}

THI was measured using dry and wet thermometer mounted in each plot of the coop $(50 \mathrm{~cm}$ above the coop's floor). Data were taken 3 times a day $(07.00 \mathrm{am}$, $12.00 \mathrm{pm}$, and $17.00 \mathrm{pm}$ ), then the THI was calculated using the following formula:

$$
\begin{aligned}
\mathrm{THI} & =0.85 \mathrm{~T}_{\mathrm{db}}+0.15 \mathrm{~T}_{\mathrm{wb}} \\
\mathrm{THI} & =\text { temperature-humidity index }\left({ }^{\circ} \mathrm{C}\right) \\
\mathrm{T}_{\mathrm{db}} & =\text { dry-bulb termperature }\left({ }^{\circ} \mathrm{C}\right) \\
\mathrm{T}_{\mathrm{wb}} & =\text { wet-bulb temperature }\left({ }^{\circ} \mathrm{C}\right)
\end{aligned}
$$

\section{Statistical Analysis}

The physical and microbiological quality data were analyzed using the analysis of variance (ANOVA). The significantly different treatments were further-tested by Duncan's multiple range test. The sensory data were analyzed by non-parametric statistical Kruskal-Wallis test (Mattjik \& Sumertajaya, 2002).

\section{RESULTS}

\section{Physical Quality of KB Rooster's Breast}

The physical qualities of KB rooster's breast data are shown in Table 1. The different stocking densities of Kampong-Broiler (KB) crossbred chicken did not affect $(\mathrm{P}>0.05)$ the physical quality, i.e. $\mathrm{pH}, \mathrm{WHC}$, and cooking loss. The $\mathrm{pH}$ value of KB chicken's meat ranged between 5.46-5.43. This $\mathrm{pH}$ value was lower compared to that of broiler, but higher than that of kampong chicken. The highest of WHC value of the KB chickens was at a density of 12 birds $/ \mathrm{m}^{2}(28.74 \pm 3.09 \%)$. The cooking losses value ranged from $40.53 \%-42.60 \%$ with a mean value of $41.36 \%$.
On the other side, stocking density significantly affected $(\mathrm{P}<0.05)$ the tenderness of the KB Rooster's breast. The cage density of 10 and $12 \mathrm{birds} / \mathrm{m}^{2}$ produced a softer breast compared to the cage density of 8 birds $/ \mathrm{m}^{2}$.

\section{Microbiological Quality of KB Rooster's Breast}

The different densities of Kampong-Broiler (KB) crossbred chicken affected $(\mathrm{P}<0.05)$ the microbiological quality of $\mathrm{KB}$ rooster's breast. However, there was no contamination of Salmonella bacteria was found in the samples (Table 2).

The breast of $\mathrm{KB}$ chickens raised in the density of 12 birds $/ \mathrm{m}^{2}$ was found to have higher TPC $(\mathrm{P}<0.05)$ compared to those raised in the densities of 8 and 10 birds/ $\mathrm{m}^{2}$. The E. coli contaminations of breast in the FB chickens raised at the densities of 8 and $10 \mathrm{birds} / \mathrm{m}^{2}$ were not significantly different, but significantly different $(\mathrm{P}<0.05)$ from those raised at the density of 12 birds $/ \mathrm{m}^{2}$ with a value of $5.70 \pm 1.28 \log \mathrm{cfu} / \mathrm{g}$. The stocking densities of 8 and 10 birds $/ \mathrm{m}^{2}$ generated the $S$. aureus contaminations of $2.71 \pm 0.02$ and $3.25 \pm 0.28 \mathrm{log} \mathrm{cfu} / \mathrm{g}$, respectively, which were lower than that of generated by the stocking density of 12 birds $/ \mathrm{m}^{2}$, i.e., $3.56 \pm 0.06 \log \mathrm{cfu} / \mathrm{g}$.

\section{Sensory Evaluation on Hedonic Quality of KB Rooster's Brisk}

The different stocking densities of $\mathrm{KB}$ crossbred chicken did not affect the aroma, taste, texture, and color appearance of the brisk (Table 3). The result showed

Table 1. Physical quality of breast meat of Kampong-broiler $(\mathrm{KB})$ rooster raised at different stocking densities

\begin{tabular}{ccccc}
\hline \multirow{2}{*}{$\begin{array}{c}\text { Density } \\
\left(\text { birds } / \mathrm{m}^{2}\right)\end{array}$} & $\mathrm{pH}$ & $\begin{array}{c}\text { Water holding } \\
\text { capacity }(\%)\end{array}$ & $\begin{array}{c}\text { Tenderness } \\
\left(\mathrm{kg} / \mathrm{cm}^{2}\right)\end{array}$ & $\begin{array}{c}\text { Cooking } \\
\text { loss }(\%)\end{array}$ \\
\cline { 2 - 5 } & $5.43 \pm 0.08$ & $27.17 \pm 2.71$ & $4.00 \pm 1.83^{\mathrm{a}}$ & $42.60 \pm 2.57$ \\
8 & $5.49 \pm 0.18$ & $27.88 \pm 1.60$ & $2.78 \pm 0.88^{\mathrm{b}}$ & $40.53 \pm 1.79$ \\
10 & $5.46 \pm 0.08$ & $28.74 \pm 3.09$ & $2.50 \pm 0.30^{\mathrm{b}}$ & $40.94 \pm 5.22$ \\
12 & $5.46 \pm 0.11$ & $27.93 \pm 2.47$ & - & $41.36 \pm 3.19$ \\
\hline
\end{tabular}

Note: Means in the same column with different superscripts differ significantly $(\mathrm{P}<0.05)$.

Table 2. Microbe population of breast meat of Kampong-broiler $(\mathrm{KB})$ rooster raised at different stocking densities (log $\mathrm{cfu} / \mathrm{g}$ )

\begin{tabular}{ccccc}
\hline \multirow{2}{*}{$\begin{array}{c}\text { Density } \\
\left.\text { (birds } / \mathrm{m}^{2}\right)\end{array}$} & \multicolumn{4}{c}{ Microbe population } \\
\cline { 2 - 5 } & TPC & E. coli & S. aureus & Salmonella \\
\hline 8 & $6.93 \pm 1.79^{\mathrm{a}}$ & $3.24 \pm 0.06^{\mathrm{a}}$ & $2.71 \pm 0.02^{\mathrm{a}}$ & Negatitive \\
10 & $6.41 \pm 0.24^{\mathrm{a}}$ & $2.89 \pm 0.06^{\mathrm{a}}$ & $3.25 \pm 0.28^{\mathrm{b}}$ & Negatitive \\
12 & $10.44 \pm 0.47^{\mathrm{b}}$ & $5.70 \pm 1.28^{\mathrm{b}}$ & $3.56 \pm 0.06^{\mathrm{b}}$ & Negatitive \\
\cline { 2 - 5 }
\end{tabular}

Note: Means in the same column with different superscripts differ significantly $(\mathrm{P}<0.05) . \mathrm{TPC}=$ total plate count. 
different stocking densities could maintain the aroma of breast meat. The range of average value of the taste found in breast was $3.19 \pm 0.83$. The texture of breast meat of KB chickens raised in different stocking densities in this study had a value of coarse to a bit coarse. The appearance of breast meat of FB chickens raised at stocking density of 8 birds $/ \mathrm{m}^{2}$ showed a brighter color, while those of FB chickens raised at stocking density of 12 birds $/ \mathrm{m}^{2}$ had the darker color.

\section{Temperature-Humidity Index (THI)}

The result indicated that the average of daily THI were $28.98 \pm 1.25^{\circ} \mathrm{C}$ for 8 birds $/ \mathrm{m}^{2}$ density, $29.26 \pm 1.27^{\circ} \mathrm{C}$ for 10 birds $/ \mathrm{m}^{2}$ density, and $29.33 \pm 1.32^{\circ} \mathrm{C}$ for 12 birds/ $\mathrm{m}^{2}$ density (Table 4). The increase in THI for each data collection was observed at the range of $2.13-2.46^{\circ} \mathrm{C}$.

\section{DISCUSSION}

\section{Physical Quality of KB Rooster's Breast}

pH value. According to Janisch et al. (2011), the range of $\mathrm{pH}$ values in breast of three different strains of broiler chickens is 5.91-5.93; while the range of $\mathrm{pH}$ values of kampong chicken's meat is $5.10-5.40$ (Dewi, 2013). This indicates that the $\mathrm{pH}$ value of KB chicken's meat is between those of broiler and kampong chicken. This difference might be due to the cross breeding and genetic differences of both broiler and kampong chickens. Stress before cutting, species, individual, and muscle type, which affect glycolysis are factors that can generate a variation in the meat $\mathrm{pH}$. The decline of $\mathrm{pH}$ up to a critical value might be caused by the decline of muscle glycogen content due to glycolysis after slaughtering as an energy source that enzymatically produced lactic acid that eventually decreased the meat $\mathrm{pH}$ (Lawrie \& Ledward, 2006). Animals which were calm during slaughtering would have enough glycogen reserves with higher $\mathrm{pH}$, while the stress animals would have lower $\mathrm{pH}$ because of the rapid use of glycogen reserves.

Table 3. Sensory evaluation on hedonic quality of breast meat of Kampong-broiler (KB) rooster raised at different stocking densities

\begin{tabular}{ccccc}
\hline \multirow{2}{*}{$\begin{array}{c}\text { Density } \\
\left(\text { birds } / \mathrm{m}^{2}\right)\end{array}$} & Aroma & Taste & Texture & Color \\
\cline { 2 - 5 } & $3.88 \pm 0.88$ & $3.23 \pm 0.70$ & $3.23 \pm 0.89$ & $3.58 \pm 0.81$ \\
8 & $3.45 \pm 0.64$ & $3.05 \pm 0.75$ & $3.03 \pm 0.66$ & $3.43 \pm 1.03$ \\
10 & $3.83 \pm 0.87$ & $3.30 \pm 1.04$ & $3.25 \pm 0.84$ & $3.15 \pm 0.70$ \\
12 & $3.72 \pm 0.80$ & $3.19 \pm 0.83$ & $3.17 \pm 0.80$ & $3.39 \pm 0.85$ \\
\hline
\end{tabular}

Note:

Aroma: 1 =very fishy, rotten, very rancid; $2=$ fishy, a bit rotten, rancid; $3=$ bit fishy; $4=$ less fishy; $5=$ typical meat, not fishy

Flavor: 1 = not tasteful; $2=$ fewer tasteful; $3=$ fewer tasteful; $4=$ tasteful; $5=$ very tasteful

Texture: 1 = very rough; $2=$ rough; $3=$ little rough; $4=$ soft, tender; $5=$ very soft, tender

Color: $1=$ very pale; $2=$ not pale; $3=$ pale; $4=$ little brighter; $5=$ bright typical meat
Water holding capacity (WHC). The ability of meat to retain water or water holding capacity (WHC) is influenced by several factors, such as $\mathrm{pH}$, production of lactic acid, and protein oxidation (Samuel et al., 2011). The range of $\mathrm{pH}$ values in this research was 5.43-5.49 and it is still in the range of normal condition. WHC has relation with $\mathrm{pH}$ in curvilinear form with minimum water holding capacity at $\mathrm{pH}$ 5.0-5.5; the $\mathrm{pH}$ value above or below this range will cause the improvement of WHC progressively (Warriss, 2001). Meat with higher WHC has better quality than meat with a low WHC. Meat with higher WHC will have more space for water molecules that will increase the meat tenderness (Sudarman et al., 2014). According to Samuel et al. (2011), meat with high WHC is perfect for refined products, because the WHC value will less decrease during cooking.

Tenderness. According to An et al. (2010), intermuscular fat can affect the tenderness by decreasing the muscle connective tissue strength, resulting in the tenderer muscle. Perimisium and endomisium are involved in determining the tenderness. The cage density of 10 and 12 birds/ $\mathrm{m}^{2}$ produced a softer breast. This might be caused by the low activity as the consequence of high density that make the limited space for the movement, the low-structured of myofibril at breast, and the lack of meat protein content. Changes in the structure of connective tissues causes improvement of tenderness in meats, while at the same time heat-denaturation of myofibrillar proteins generally causes meats toughening (Li et al., 2013).

Cooking loss. According to Hartono et al. (2013), cooking loss is also influenced by $\mathrm{pH}$. This study found a relatively similar breast $\mathrm{pH}$ value of $\mathrm{KB}$ chicken that was between $5.43 \pm 0.08-5.49 \pm 0.18$ that eventually resulted in the relatively similar cooking loss. According to Dilaga (2012), a good quality meat has a low cooking loss due to the low nutrients loss during cooking.

\section{Microbiological Quality of KB Rooster's Breast}

Total Plate Count (TPC). The contamination of carcass was majority obtained from the fecal contamination during carcass preparation. According to Berrang et al. (2011), bacteria found in the carcass were obtained from the air or feces contaminating the skin and meat. The brisk is located close to the internal organs and digestive tract that has a higher chance of microbial contamination (Irmanita et al., 2016).

Table 4. Average temperature humidity index (THI) cages of Kampong-broiler (KB) chickens raised at different stocking densities

\begin{tabular}{|c|c|c|c|c|}
\hline \multirow{2}{*}{$\begin{array}{l}\text { Density } \\
\left(\text { birds } / \mathrm{m}^{2}\right)\end{array}$} & \multicolumn{3}{|c|}{ Time } & \multirow{2}{*}{$\begin{array}{c}\text { Daily average } \\
\text { of THI }\end{array}$} \\
\hline & 7 a.m. & 12 p.m. & 17 p.m. & \\
\hline 8 & $27.50 \pm 1.44$ & $29.63 \pm 1.26$ & $29.82 \pm 1.04$ & $28.98 \pm 1.25$ \\
\hline 10 & $27.57 \pm 1.47$ & $30.03 \pm 1.28$ & $30.19 \pm 1.06$ & $29.26 \pm 1.27$ \\
\hline 12 & $27.71 \pm 1.61$ & $30.10 \pm 1.29$ & $30.18 \pm 1.07$ & $29.33 \pm 1.32$ \\
\hline
\end{tabular}


Fresh chicken meat has enough water content and at room temperature this condition will be an ideal media for the growth of pathogenic bacteria (Kusumaningrum et al., 2013). The safety and feasibility of chicken meat should be prioritized as early as possible (Aerita, 2014) because chicken meat is vulnerable to contamination by microorganisms prior to harvesting or cutting (primary contamination) and after harvesting or cutting (secondary pollution).

Escherichia coli. The E. coli contamination of breast in the FB chickens raised at the density of $10 \mathrm{birds} / \mathrm{m}^{2}$ was lower than those of raised at densities of 8 and 12 birds/ $\mathrm{m}^{2}$. Contamination of chicken meat from surrounding environment occurs continuously from bleeding until consumption. According to Morshedy \& Sallam (2009), the scalding, plucking, and eviscerating stages have significant effects on bacterial contamination. Sanitation and handling are also favorable factors of E. coli contamination in the food products processing (Dewantoro et al., 2009).

Staphylococcus aureus. The sources of S. aureus found in the breast can be the contents of the digestive tract. According to Berrang et al. (2011), the contaminated bacteria found on the carcass might be originated from the air or feces.

Based on SNI 01-3924-2009 standard, the number of $S$. aureus population in the breast of $\mathrm{FB}$ chickens raised at the density of 8 birds $/ \mathrm{m}^{2}$ is still in a normal range, while that of $\mathrm{FB}$ chickens raised at the densities of 10 and 12 birds $/ \mathrm{m}^{2}$ were beyond the maximum limit. According to Nurwantoro et al. (2011), the cases of food poisoning are usually occurred if the $S$. aureus population reached $10^{8} \mathrm{cfu} / \mathrm{g}$ or more.

Salmonella sp. Salmonella is the zoonotic foodborne disease causing pathogen (Russell, 2012). The test result indicated the negative result of Salmonella in breast (Table 2). According to SNI 01-3924-2009 about the maximum microbial contamination in food, the good quality chicken's meat must not contain Salmonella sp.

\section{Sensory Evaluation on Hedonic Quality of KB Rooster's Breast}

The hedonic quality found in the breast ranged from a bit fishy to a less fishy. This reault indicated that different stocking densities could maintain the aroma of breast meat. According to Kamboh \& Zhu (2013), chicken meat has a relatively low fat content and high concentration of polyunsaturated fatty acids (PUFA). A high level of polyunsaturation accelerates lipid peroxidation, leading to deterioration of meat odor, color, texture, flavor, and nutritional value (Toufektsian et al., 2011). Besides, the smell of breast was difficult to be distinguished by the panelists, causing no different was found in the aroma among the breast meat of FB chickens raised at different stocking densities.

According to Jayasena et al. (2013), the taste and aroma of meats are important in determining the meat quality. Various meats have distinctive traits in taste.
The taste of meat is affected by the strain of chickens, feed, and cooking process (Jayasena et al., 2013). The volatile contents in the meat react to their receptors in the mouth that will eventually determine the meat quality that tastes relatively tasteful (Owens, 2010).

The texture of breast meat of FB chickens raised in different stocking densities in this study had a value of coarse to a bit coarse. The meat texture might be affected by $\mathrm{pH}$ (Abustam, 2012). According to Jayasena et al. (2013), the range of $\mathrm{pH}$ from 5.1 to 6.1 causes an open structure of meat that improves the easiness of teeth in cutting the meat into smaller fragments. This means that the meat fibers are almost at the same appearance. The meat texture is affected by connective tissue content, especially collagen, that have a role in determining the hardness of muscle (Abustam, 2012). According to Jung et al. (2013), the breast consists of $90 \%$ white muscle fibers.

Colors are elements that may affect consumer acceptance of products. The breast meat of KB chickens with stocking density showed a brighter color than the other densities. The bright colored meat, both inside and surface, is preferred by consumers (De Marchi et al., 2011).

\section{Temperature-Humidity Index (THI)}

THI is a single value representing the combined effects of air temperature and humidity associated with the level of thermal stress and indices differ in their ability to detect heat stress (Bohmanova et al., 2007). The stocking density increased THI range. However, stocking density did not affect the quality of breast meat. Uncomfortable environments is a controlling factor in energy metabolism. The uncomfortable condition in cages, such as high temperature, will push chickens to remove the heat inside the body through painting. The body temperature of an adult chicken is 40.6-41.7 ${ }^{\circ} \mathrm{C}$, and the thermoneutral zone that allows chickens to maintain their normal body temperature is $18-24^{\circ} \mathrm{C}$ (Olanrewaju et al., 2010).

\section{CONCLUSION}

The high density increased THI value but did not affect the physical and hedonic quality of $\mathrm{KB}$ chicken breast, so it could be accepted by consumers. High density increased TPC, E. coli, and S. aureus contamination, but Salmonella contamination was not found. The meat quality at the stocking density of $10 \mathrm{birds} / \mathrm{m}^{2}$ still met the standard of SNI 01-3924-2009.

\section{REFERENCES}

Abustam, E. 2012. Ilmu daging: Aspek produksi, Kimia, Biokimia dan Kualitas. Masagena Press, Makasar.

Aerita, A. N. 2014. Hubungan higiene pedagang dan sanitasi dengan kontaminasi Salmonella pada daging ayam potong. Unnes Journal of Public Health 3(4): 9-16.

An, J. Y., J. X. Zheng, J. Y. Li, D. Zeng, L. J. Qu, G. Y. Xu, \& N. Yang. 2010. Effect of myofiber characteristics and thickness of perimysium and endomysium on meat tenderness of chickens. Poultry Sci. 89: 1750-1754. http://dx.doi. 
org/10.3382/ps.2009-00583

Arief, I. I., T. Suryati, D. Afiyah, \& D. Wardhani. 2014. Physicochemical and organoleptic of beef sausages with teak leaf extract (Tectona grandis) addition as preservative and natural dye. International Food Research Journal 21: 2033-2042.

Berrang, M., W. Windham, \& R. Meinersmann. 2011. Campylobacter, Salmonella, and Escherichia coli on broiler carcasses subjected to a high $\mathrm{pH}$ scald and low $\mathrm{pH}$ postpick chlorine dip. Poultry Sci. 90: 896-900. http://dx.doi. org/10.3382/ps.2010-00900

Berri, C., J. Besnard, \& C. Relandeau. 2008. Increasing dietary lysine increases final $\mathrm{pH}$ and decreases drip loss of broiler breast meat. Poultry Sci. 87: 480-484. http://dx.doi. org/10.3382/ps.2007-00226

Bohmanova, J., I. Misztal, \& J. Cole. 2007. Temperaturehumidity indices as indicators of milk production losses due to heat stress. J. Dairy Sci. 90: 1947-1956. http://dx.doi. org/10.3168/jds.2006-513

Bowker, B. C., H. Zhuang, \& R. J. Buhr. 2014. Impact of carcass scalding and chilling on muscle proteins and meat quality of broiler breast fillets. LWT-Food Science and Technology 59: 156-162. http://dx.doi.org/10.1016/j.lwt.2014.05.008

Cengiz, Ö., B. H. Köksal, O. Tatlı, Ö. Sevim, U. Ahsan, A. G. Üner, et al., 2015. Effect of dietary probiotic and high stocking density on the performance, carcass yield, gut microflora, and stress indicators of broilers. Poultry Sci. 94: 2395-2403. http://dx.doi.org/10.3382/ps/pev194

De Marchi, M., M. Penasa, M. Battagin, E. Zanetti, C. Pulici, \& M. Cassandro. 2011. Feasibility of the direct application of near-infrared reflectance spectroscopy on intact chicken breasts to predict meat color and physical traits. Poultry Sci. 90: 1594-1599. http://dx.doi.org/10.3382/ps.2010-01239

Dewantoro, G. I., M. Adiningsih, T. Purnawarman, T. Sunartatie, \& U. Afiff. 2009. Tingkat prevelansi Echerichia coli dalam daging ayam beku yang dilalulintaskan melalui pelabuhan Merak. Jurnal Ilmu Pertanian Indonesia 14: 211-216.

Dewi, S. H. C. 2013. Kualitas kimia daging ayam kampung dengan ransum berbasis konsentrat broiler. Jurnal AgriSains 4: $42-49$.

Dilaga, I. W. S. 2012. Pengaruh pemberian berbagai level Clenbuterol terhadap kualitas daging babi jantan grower. Buletin Peternakan 31: 200-208. http://dx.doi.org/10.21059/ buletinpeternak.v31i4.1237

FDA, U., U. Food, \& D. Administration. 2001. Bacteriological analytical manual online. Available from: $<$ Available from: http://www. fda. gov/Food/FoodScienceResearch/ LaboratoryMethods/ucm2006949. htm>. Acessed: fev 2: 2015.

Feddes, J., E. Emmanuel, \& M. Zuidhoft. 2002. Broiler performance, body weight variance, feed and water intake, and carcass quality at different stocking densities. Poultry Sci. 81: 774-779. http://dx.doi.org/10.1093/ps/81.6.774

Gustira, D. E., \& T. Kurtini. 2015. Pengaruh kepadatan kandang terhadap performa produksi ayam petelur fase awal grower. Jurnal Ilmiah Peternakan Terpadu 3: 87-92.

Hartono, E., N. Iriyanti, \& R. Santosa. 2013. Pengaruh pakan fungsional terhadap daya ikat air, susut masak dan keempukan daging ayam broiler. Jurnal Ilmiah Peternakan 1: 10-19.

Honikel, K., \& R. Hamm. 1994. Measurement of water-holding capacity and juiciness. Springer, London, UK. http:// dx.doi.org/10.1007/978-1-4615-2167-9 5

Irmanita, V., A. K. Wardani, \& H. Harsojo. 2016. Pengaruh iradiasi Gamma terhadap kadar protein dan mikrobiologis daging ayam broiler pasar tradisional dan pasar modern Jakarta Selatan. Jurnal Pangan dan Agroindustri 4: 428-435.

Iskandar, S., S. Setyaningrum, Y. Amanda, \& I. Soesanto. 2014.
Pengaruh kepadatan kandang terhadap pertumbuhan dan prilaku ayam Wareng-Tangerang dara. JTTV 19: 19-24.

Janisch, S., C. Krischek, \& M. Wicke. 2011. Color values and other meat quality characteristics of breast muscles collected from 3 broiler genetic lines slaughtered at 2 ages. Poultry Sci. 90: 1774-1781. http://dx.doi.org/10.3382/ ps.2010-01073

Jayalakshmi, T., R. Kumararaj, T. Sivakumar, T. T. Vanan, \& D. Thiagarajan. 2009. Influence of stocking densities on litter moisture, microbial load, air ammonia concentration and broiler performance. Tamilnadu J. Vet. Anim. Sci 5: 80-86.

Jayasena, D. D., D. U. Ahn, K. C. Nam, \& C. Jo. 2013. Flavour chemistry of chicken meat: A review. Asian Australas. J. Anim. Sci. 26: 732-742. http://dx.doi.org/10.5713/ ajas.2012.12619

Jung, S., Y. S. Bae, H. J. Kim, D. D. Jayasena, J. H. Lee, H. B. Park, K. N. Heo, \& C. Jo. 2013. Carnosine, anserine, creatine, and inosine 5'-monophosphate contents in breast and thigh meats from 5 lines of Korean native chicken. Poultry Sci. 92: 3275-3282. http://dx.doi.org/10.3382/ ps.2013-03441

Kamboh, A. \& W.-Y. Zhu. 2013. Effect of increasing levels of bioflavonoids in broiler feed on plasma anti-oxidative potential, lipid metabolites, and fatty acid composition of meat. Poultry Sci. 92: 454-461. http://dx.doi.org/10.3382/ ps.2012-02584

Kirmaci, B., \& R. K. Singh. 2012. Quality of chicken breast meat cooked in a pilot-scale radio frequency oven. Innovative Food Science \& Emerging Technologies 14: 77-84. http:// dx.doi.org/10.1016/j.ifset.2012.01.003

Kusumaningrum, A., P. Widiyaningrum, \& I. Mubarok. 2013. Penurunan total bakteri daging ayam dengan perlakuan perendaman infusa daun salam (Syzygium polyanthum). Jurnal MIPA 36: 14-19.

Lawrie, R., \& D. Ledward. 2006. Lawrie's meat science. Cambridge: Woodhead Publishing Limited. http://dx.doi. org/10.1533/9781845691615

Li, C., D. Wang, W. Xu, F. Gao, \& G. Zhou. 2013. Effect of final cooked temperature on tenderness, protein solubility and microstructure of duck breast muscle. LWT-Food Science and Technology 51: 266-274. http://dx.doi.org/10.1016/j. lwt.2012.10.003

Mattjik, A. A., \& I. M. Sumertajaya. 2002. Perancangan percobaan dengan aplikasi SAS dan Minitab. Jilid I. Edisi ke-2. Institut Pertanian (IPB)-Press, Bogor.

Morshedy, A., \& K. I. Sallam. 2009. Improving the microbial quality and shelf life of chicken carcasses by trisodium phosphate and lactic acid dipping. International Journal of Poultry Science 8: 645-650. http://dx.doi.org/10.3923/ ijps.2009.645.650

Nurwantoro, N., V. Bintoro, A. Legowo, L. Ambara, A. Prakoso S. Mulyani, \& A. Purnomoadi. 2011. Microbiological and physical properties of beef marinated with garlic juice. Journal of the Indonesian Tropical Animal Agriculture 36: 166-170. http://dx.doi.org/10.14710/jitaa.36.3.166-170

Olanrewaju, H., J. Purswell, S. Collier, \& S. Branton. 2010. Effect of ambient temperature and light intensity on physiological reactions of heavy broiler chickens. Poultry Sci. 89: 2668-2677. http://dx.doi.org/10.3382/ps.2010-00806

Owens, C. M., 2010. Poultry Meat Processing. CRC Press, Boca Raton.

Russell, S. M., 2012. Controlling Salmonella in poultry production and processing. CRC Press. http://dx.doi.org/10.1201/ b11519

Samuel, D., B. Park, M. Sohn, \& L. Wicker. 2011. Visible-nearinfrared spectroscopy to predict water-holding capacity in normal and pale broiler breast meat. Poultry Sci. 90: 914921. http://dx.doi.org/10.3382/ps.2010-01116

Sudarman, A., M. Muttakin, \& H. Nuraini. 2014. Penambahan 
sabun-kalsium dari minyak ikan lemuru dalam ransum: 2 pengaruhnya terhadap sifat kimia dan fisik daging domba. JITV 19: 133-139.

Tao, X., \& H. Xin. 2003. Acute synergistic effects of air temperature, humidity, and velocity on homeostasis of marketsize broilers. Transactions of the ASAE 46: 491.

Tijare, V., F. Yang, V. Kuttappan, C. Alvarado, C. Coon, \& C. Owens. 2016. Meat quality of broiler breast fillets with white striping and woody breast muscle myopathies. Poultry Sci.: 1-7. http://dx.doi.org/10.3382/ps/pew129

Toufektsian, M.-C., P. Salen, F. Laporte, C. Tonelli, \& M. De Lorgeril. 2011. Dietary flavonoids increase plasma very long-chain (n-3) fatty acids in rats. The Journal of Nutrition 141: 37-41. http://dx.doi.org/10.3945/jn.110.127225

Vanhonacker, F., W. Verbeke, E. Van Poucke, S. Buijs, \& F. A. Tuyttens. 2009. Societal concern related to stocking density, pen size and group size in farm animal production. Livestock Sci. 123: 16-22. http://dx.doi.org/10.1016/j. livsci.2008.09.023

Warriss, P. D. 2001. Meat Science. CABI, Oxfordshire.

Zuowei, S., L. Yan, L. Yuan, H. Jiao, Z. Song, Y. Guo, \& H. Lin. 2011. Stocking density affects the growth performance of broilers in a sex-dependent fashion. Poultry Sci. 90: 14061415. http://dx.doi.org/10.3382/ps.2010-01230 